\title{
Water Purification Using a Solar Still Coupled With Evacuated Tube Collector
}

\author{
Simi Shoukathali ${ }^{1}$, Sonia Dathan ${ }^{2}$, Mary George ${ }^{3}$ \\ ${ }^{1}$ Assistant Professor, Mount Zion College of Engineering, Kadamanitta, Pathanamthitta 689649, India \\ ${ }^{2}$ Assistant Professor, Mount Zion College of Engineering, Kadamanitta, Pathanamthitta 689649, India \\ ${ }^{3}$ Assistant Professor, Mount Zion College of Engineering, Kadamanitta, Pathanamthitta 689649, India
}

\begin{abstract}
There is an urgent need of clean, pure drinkable water. Often water sources are brackish and or contain harmful bacteria and therefore cannot be used for drinking.. Pure water is also needful in some industries, hospitals and schools. Distillation is one of many processes that can be used for water purification. Solar radiation can be used as the source of heat energy. In this process, water is evaporated and thus separating water vapour from dissolved substances, and is then condensed as pure water by using a still integrated with ETC (Evacuated Tube Collector) then the performance analysis is calculated and is compared with passive still. It was found that the amount of distilled water from still with ETC is more than that from a passive one.
\end{abstract}

Keywords: Solar distillation, solar still, Evacuated Tube Collector

\section{Introduction}

Water is most essential for human life and is being polluted by human activities, urbanization and industrialization. The ground water is often over exploited to meet the increasing demand of the people. Less than $1 \%$ of earth's water is using for human consumption and more than 1.2 billion people still have no access to safe drinking water. Over $50 \%$ of the world population is estimated to be residing in urban areas, and almost $50 \%$ of mega cities having population over 10 million are heavily dependent on ground water, especially in the developing countries like India. Nearly half of the population is illiterate, not at all aware of the waterborne diseases affecting their health. Nearly $70 \%$ of the infectious diseases in India are waterborne. Indian villages are posed with problem of overexploitation of ground water due to increasing dependence on it as other fresh water resources are dwindling fast. There is an important need for clean, pure drinking water in many developing countries. Often water sources are brackish (i.e. contain dissolved salts) and/or contain harmful bacteria and therefore cannot be used for drinking. However, boiling is relatively expensive, consumes substantial amounts of fossil energy and the associated wood gathering contributes to depletion of forests. Energy resources are getting depleted day by day at a very alarming rate. So continuous research is going on around the world to harness energy from other renewable sources. While we think of the word "Renewable" the very first thing that comes to our mind is "Solar". With about 300 clear sunny days in a year India receives about 5 Petawatt-hours per year (Pwh/year) (i.e; 5 trillion Kwhr/day). For example, assuming if losses are minimized and processes optimized with better ideas and better technology, solar energy has enough potential to cater to the needs of modern man So among available alternatives, solar water purification is one of the approaches for an energy-efficient, cost-effective, robust and reliable solution to these problems.

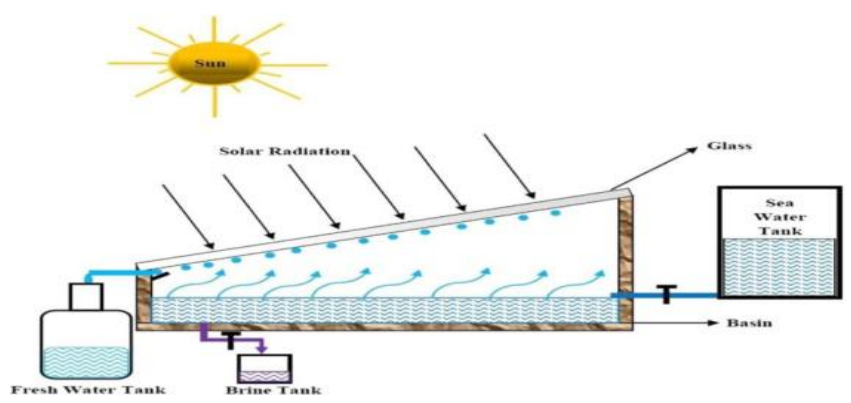

Figure 1: Schematic diagram of solar still

For high efficiency the solar still should maintain: A high feed (undistilled) water temperature

- A large temperature difference between feed water and condensing surface

A high feed water temperature can be achieved if:

- A high proportion of incoming radiation is absorbed by the feed water as heat.

\section{Solar Still}

In Solar water distillation a solar still is used to condense pure water vapor and settle out harmful substances to make clean, pure drinking water. A solar still operates similar to the natural hydrologic cycle of evaporation and condensation. In it the basin is filled with impure water and the sun rays are passed through the glass cover to heat the water in the basin and the water gets evaporated. As the water evaporates, it leaves all contaminates and microbes in the basin. The purified water vapour condenses on the inner side of the glass, runs through the lower side of the still and then gets collected in a closed container. Many solar distillation systems were developed over the years using the above principle for water purification in many parts of the world.

The solar distillation systems are mainly classified as passive solar still and active solar still. The parameters affecting the performance of the still are water depth, material of the basin, 


\section{International Journal of Science and Research (IJSR) \\ ISSN (Online): 2319-7064}

Index Copernicus Value (2015): 78.96 | Impact Factor (2015): 6.391

wind velocity, solar radiation, ambient temperature and inclination angle. The temperature difference between the water in the basin and inner surface glass cover determines the productivity of the still. In a passive solar still, the solar radiation is received directly by the basin water and is the only source of energy for raising the water temperature and consequently, the evaporation leading to a lower productivity. This is the main drawback of a passive solar still.in order to overcome the above problem; many active solar stills have been developed. Here, an extra thermal energy is supplied to the basin through an external mode to increase the evaporation rate which in turn improves its productivity.

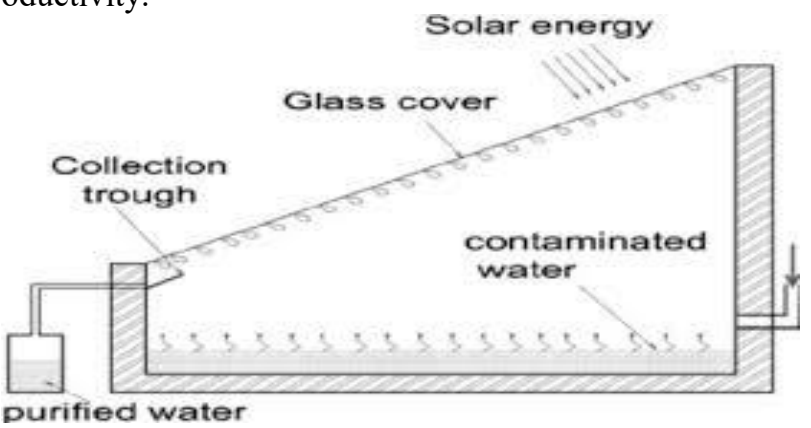

Figure 2: Solar still

\section{Evacuated Tube Collector}

Evacuated Tube Collectors (ETC) has higher efficiencies when compared to flat plate solar collectors. In flat plate collectors, at noon sunrays are perpendicular to the collector and thus a proportion of the sunlight striking the surface of the collector is reflected. But in evacuated tube collector, because of its cylindrical shape, the sun rays are perpendicular to the surface of the glass for most of the day. The evacuated tubes greatly reduce the heat losses as vacuum is present in the tubes. The evacuated tube collector consists of two coaxial tubes with evacuated space between an outer surface of inner tube and inner surface of the outer tube. A selective coating is applied to the outer surface of the inner tube. The heat transfer fluid enters through the tube and exits from the same end of the tube through annular space between delivery tube and selective coated absorber tube (which is sealed from one end)

\section{Experimental Setup}

A water desalination unit was designed and fabricated and experiments were performed from January to April, 2015. A simple conventional solar still was fabricated and coupled with evacuated tubes. Three evacuated tubes were used. The inner dimensions of the still are $1 \times 0.6 \mathrm{~m}$, with a collector surface area of $905 \times 595 \mathrm{~mm}$ respectively. The basin structure of the solar still was composed of mild steel plate. The inner side of the basin was painted black to maximize the absorption of solar radiation. The bottom and sides of the still basin are well insulated with a glass wool layer of $50 \mathrm{~mm}$ thickness. An ordinary clear window with a glass thickness of $5 \mathrm{~mm}$ was used as the top cover of the solar still and inclined at an angle of $30^{\circ}$. The total experimental setup was arranged to face in the southerly direction to receive the maximum solar radiation. A silicon rubber sealant was used as the seal between the glass cover and body of the solar still to prevent leakage at the seam. The distillate water condensed from the glass cover was collected in a distillation trough. Evacuated tubes were also tilted at angle of $30^{\circ}$. Solar still coupled with evacuated tube was placed on movable iron stand. Supply of brackish water was given to the solar still through inlet port. A float valve was used inside the solar still for maintain different heights. A channel was attached at low side of solar still so that water vapors slide on glass cover and after condensation could be collected in channel. This distillation yield was collected in the measuring jar with the help of pipe through provided outlet. The solar radiations, ambient temperature, temperature of the basin, brackish water, glass cover and distilled water temperatures were measured after every $1 \mathrm{~h}$.

Table 1(a): Design parameters of Solar Still

\begin{tabular}{|l|l|}
\hline Area of basin & $0.54 \mathrm{~m}^{2}$ \\
\hline Material & Mild steel \\
\hline \multicolumn{2}{|c|}{ Glass cover } \\
\hline Thickness & $5 \mathrm{~mm}$ \\
\hline Inclination & $30^{\circ}$ \\
\hline \multicolumn{2}{|c|}{ Insulation } \\
\hline Material & Glass wool \\
\hline Thickness & $50 \mathrm{~mm}$ \\
\hline
\end{tabular}

Table 1(b): Design parameters of ETC

\begin{tabular}{|l|l|}
\hline Length & $1500 \mathrm{~mm}$ \\
\hline Outer diameter & $50 \mathrm{~mm}$ \\
\hline Inner diameter & $40 \mathrm{~mm}$ \\
\hline Storage box & $330 \times 180 \mathrm{~mm}$ \\
\hline Number of tubes used & 3 \\
\hline
\end{tabular}

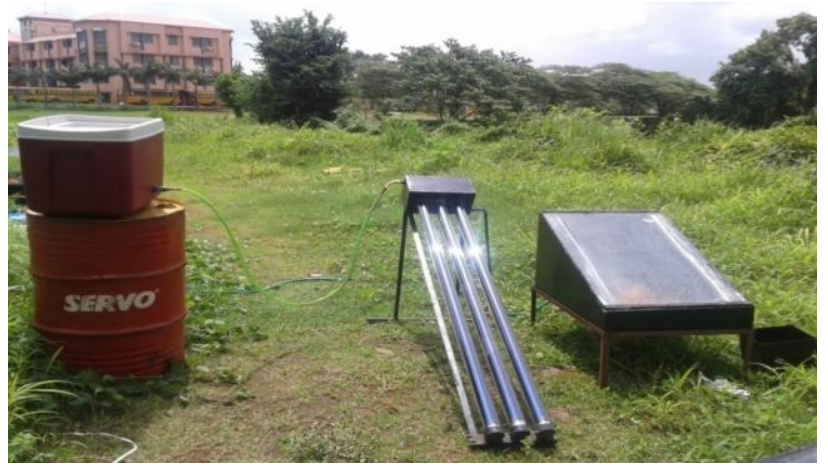

Figure 1: Experimental Setup of Still with Evacuated Tube Collector

Firstly basin and evacuated tubes were filled with brackish water up to the required water depth. Continuous flow inside the basin of solar still was maintained with the help of float valve. The Evacuated tubes consist of two concentrating borosilicate glass tube with evacuated space between them. The water inside inner tube gets heated and moves toward the basin and cold water comes inside the tube. Due to this thermo-syphon process water in solar still gets heated and evaporation rate in solar still get increased. The main advantage of evacuated tube over other collector is zero convective loss and no requirement of tracking. The temperatures were measured using thermocouples $\left( \pm 1^{\circ} \mathrm{C}\right)$ and they were linked to a digital temperature indicator. The ambient temperature was also measured. The solar radiation intensity was measured by solarimeter.

\section{Volume 6 Issue 1, January 2017




\section{International Journal of Science and Research (IJSR) \\ ISSN (Online): 2319-7064}

Index Copernicus Value (2015): 78.96 | Impact Factor (2015): 6.391

\section{Results and Discussions}

The temperature at different points of desalination unit is measured after every 1 hour time interval during day time from 9:00a.m to 4:00 p.m. Various parameters has significant effect on the productivity of still. Basin water temperature and inner glass cover temperature are the most influential parameters on the yield of still. Besides this, the intensity of solar radiation is a key parameter in determining the efficiency of still. For each experimental case, readings were taken for three consecutive days so that optimum reading can be chosen from the three to ensure that all parameters are measured under maximum clear sky conditions and to for sake any unfavorable weather condition

\section{Basin Water Temperature}

Fig. shows the variation of basin water temperature for two different cases. From the Figure it is inferred that, maximum basin temperature of $49^{\circ} \mathrm{C}$ was obtained in the case of single slope solar still coupled with ETC and at 1 P.M, which was approximately $10^{\circ} \mathrm{C}$ higher than the basin temperature of solar still coupled w. This was due to the additional thermal energy fed into the basin of solar still by ETC

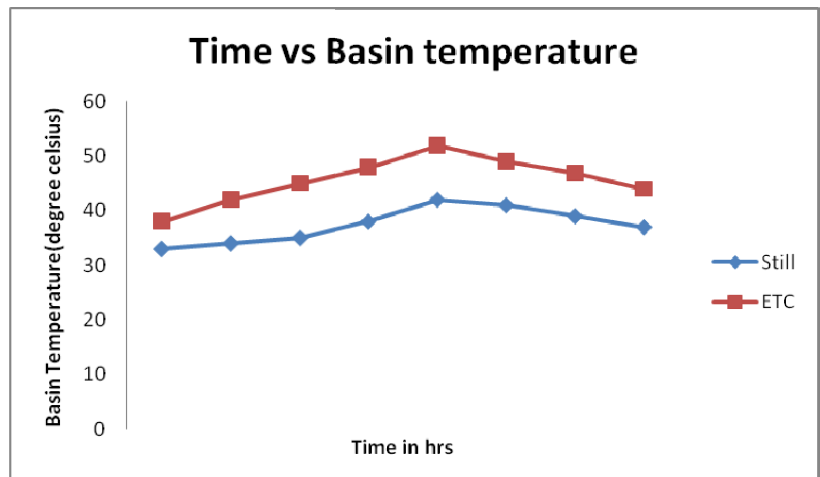

Figure 2: Variation in Basin Temperature

\section{Inner Glass Cover Temperature}

Fig. 3 shows the variation of inner glass cover temperature for three different cases. Maximum inner glass cover temperature of $48^{\circ} \mathrm{C}$ was obtained in the case of single solar still coupled with ETC at 1 P.M, followed by $40^{\circ} \mathrm{C}$ in the case of solar still.

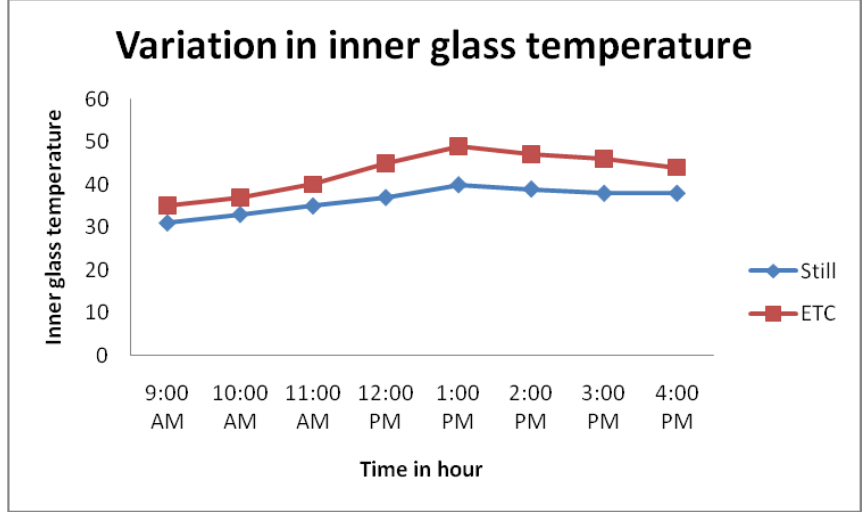

Figure 3: Variation in Temperature Difference

\section{Flow Rate}

By adjusting the flowrate of water to the still, a graph is plotted. From the graph it is inferred that yield from the still increases as rate of flow increases up to $3 \mathrm{~m} / \mathrm{s}$. At $4 \mathrm{~m} / \mathrm{s}$ yield decreases.

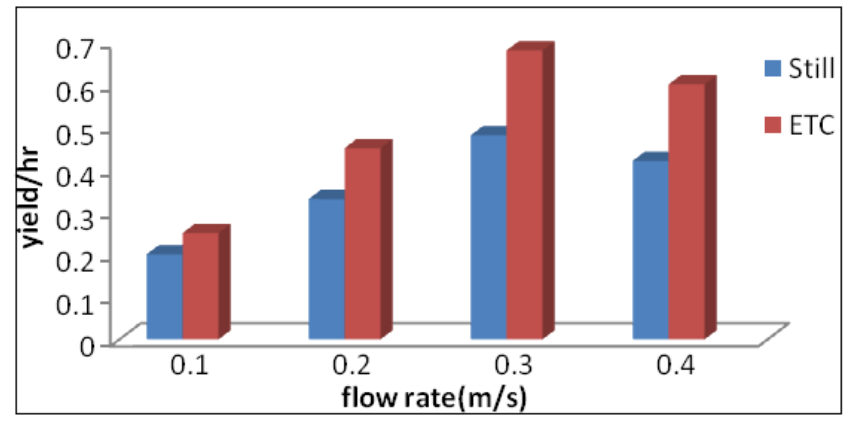

Figure 4: Yield Vs Flow Rate

Yield of Different Samples

Different samples of water has different evaporation rate. Tap water has more evaporation rate than others as it doesn't have any dissolved substances. A graph is plotted with the evaporation rate of different samples.

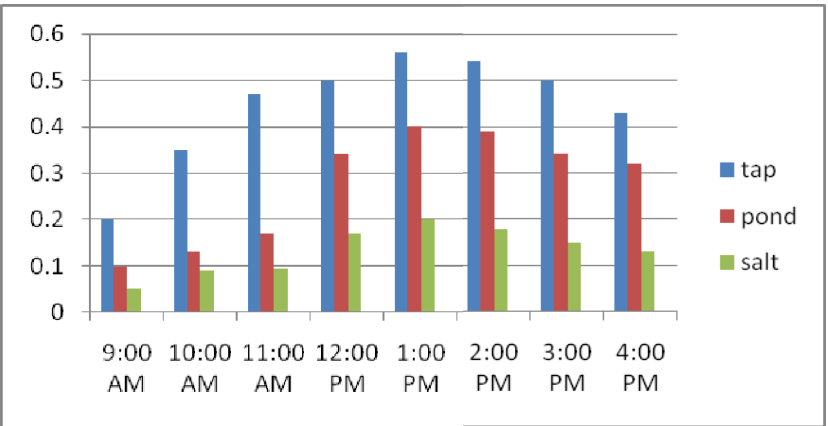

Figure 5: Yield Vs Time (Different Samples)

The efficiency of still with ETC was calculated by

$\mathrm{\eta}=\frac{\sum m_{w} \times L}{\sum I\left(t_{s}\right) \times A_{g s} \times t+\sum I\left(t_{c}\right) \times A_{e t} \times t}$

Where,

$\sum \mathrm{I}\left(\mathrm{t}_{\mathrm{c}}\right)$ is the intensity of solar radiation over the inclined surface of solar collector $\left(\mathrm{W} / \mathrm{m}^{2}\right)$.

$\mathrm{A}_{\mathrm{et}}$ is the surface area of absorber tube

$\sum \mathrm{I}\left(\mathrm{t}_{\mathrm{s}}\right)$ is the intensity of solar radiation over the inclined surface of solar still $\left(\mathrm{W} / \mathrm{m}^{2}\right)$

\section{Conclusion}

Water desalination unit is established by coupling single slope single basin solar still with evacuated tube. Natural flow of water occurs through tube due to thermo-syphon principle. Major finding of this work is

- Thermo-syphon principle work successfully for heating of water inside the desalination unit and is helpful in increasing the temperature of water during working of system.

- Integration of evacuated tubes helps in increasing the water temperature inside the basin and inside the evacuated tubes 


\section{Future Directions}

More work has to be performed on solar still from research point of view for meeting demands of society. Some important work have to be done in future is listed below

- The still can be modified to have a higher temperature in the basin water by providing a layer of heat absorbing materials such as tar, gravel, metal chips etc. This can help in increasing the temperature to a higher level.

- Sprinkler or cooling film can be used to increase the condensation of the water vapor and increases the productivity.

- The productivity can be improved by making a double slope solar still.

- To enhance the absorptivity of solar radiation dissolved salts like pottassium permanganate and pottassium dichromate can be used.

- The productivity can also be increased by improving the thermal performance of Flat Plate Collector. This is accomplished by employing an aluminium grid placed in the channels of a collector to induce a gradient of heat capacitance

\section{References}

[1] Muafag Suleiman K. Tarawneh Effect of Water Depth on the Performance Evaluation of Solar Still", Jordan Journal of Mechanical and Industrial Engineering, Vol 1, No 1,pp: 23-29Sep. 2007.

[2] Syed Firozuddin, Dr. P. V. Walke, Thermal Performance on Single Basin Solar Still with Evacuated Tubes Solar Collector-A review." International Journal of Modern Engineering Research, Vol.3, No 2, pp: 1022-1025, Mar 2009.

[3] A.A. Satam A Descriptive Study of the Constructional Features of Evacuated Tube Solar Water Heating System", IOSR Journal of Mechanical and Civil Engineering Vol 2,No 3,pp:36-41,Apr 2009.

[4] V. Velmurugan, S.Senthil Kumaran, V. Niranjan Prabhu, and K.Srithar, Productivity Enhancement of Stepped Solar Still- Performance Analysis", Desalination, Vol 3, No 1, pp:28-41,Jan2009.

[5] Rajesh. A.M, Bharath. K.N, Babu Kumar B R, Đesign and Performance of Hybrid Solar Still", International Conference on Control, Automation, Communication and Energy Conservation, Vol 3, No 1,pp: 33-40, June 2009.

[6] K. Sampathkumar, T.V. Arjunan, P. Pitchandi Active solar distillation-A detailed review" Renewable and Sustainable Energy Reviews, Vol14, No 4, pp: 15031526, Feb 2010. 